\title{
PENGARUH IDEALISME, PENGALAMAN, DAN KOMITMEN PROFESIONAL PADA PEMBUATAN KEPUTUSAN ETIS KONSULTAN PAJAK TERDAFTAR DI WILAYAH BALI-NUSA TENGGARA
}

\author{
I Made Dwi Harmana ${ }^{1}$ \\ Made Gede Wirakusuma ${ }^{2}$ \\ Dewa Gede Wirama ${ }^{3}$
}

\author{
${ }^{1,2,3}$ Fakultas Ekonomi dan Bisnis Universitas Udayana (Unud), Bali, Indonesia \\ Email: dwiharmana@gmail.com
}

\begin{abstract}
ABSTRAK
Penelitian ini bertujuan untuk mengetahui pengaruh idealisme, pengalaman, dan komitmen profesional pada pembuatan keputusan etis konsultan pajak terdaftar di wilayah Bali-Nusa Tenggara. Penelitian ini menggunakan data primer yaitu berdasarkan jawaban responden atas kuisioner yang disebarkan pada 114 orang Konsultan Pajak terdaftar di Wilayah Bali-Nusa Tenggara. Teknik penentuan sampel menggunakan purposive sampling. Populasi dalam penelitian ini adalah seluruh anggota IKPI (Ikatan Konsultan Pajak Indonesia) Wilayah Bali-Nusa Tenggara sebanyak 114 orang dan berdasarkan kriteria yang ditentukan jumlah sampel sebanyak 90 orang. Teknik analisis data dilakukan dengan menggunakan teknik analisis regresi linier berganda. Hasil analisis menunjukkan bahwa idealisme, pengalaman, dan komitmen professional berpengaruh positif pada pembuatan keputusan etis konsultan pajak.
\end{abstract}

Kata kunci: Idealisme, Pengalaman, Komitmen Profesional, Keputusan Etis

\begin{abstract}
This study aims to determine the influence of idealism, experience and professional commitment to ethical decision-making of registered tax consultant in the territory of BaliNusa Tenggara. This study uses primary data that based on respondent's answers on questionnaires that were distributed to 114 Registered Tax Consultant in the Territory of Bali-Nusa Tenggara. Sampling technique used is purposive sampling. The population uses all member of IKPI (Association of Tax Consultants Indonesia) Bali-Nusa Tenggara region as many as 114 people and based on criteria, specified number of samples are 90 people. The analysis shows that the idealism, experience, and professional commitment have positive impact to ethical decision making of registered tax consultant.
\end{abstract}

Keywords: Idealism, Experience, Commitment Professional, Ethical Decision 


\section{PENDAHULUAN}

Indonesia merupakan negara yang sumber pendapatannya sebagian besar berasal dari pajak. Rasio penerimaan perpajakan Indonesia saat ini masih berada di kisaran 11 persen dimana rasio tersebut masih berada di bawah standar negaranegara ASEAN dan Organisation on Ecomomic Cooperation and Development (OECD) (www.kemenkeu.do.id). Hingga 20 Desember 2016 penerimaan negara dari pajak mencapai Rp 1.032,2 triliun atau 76,17 persen dari target APBN-P pada tahun 2017 yaitu sebesar Rp 1.355,2 triliun (www.beritasatu.com). Berbagai upaya dilakukan oleh pemerintah untuk meningkatkan realisasi penerimaan pajak dan rendahnya rasio penerimaan pajak tersebut. Salah satu upaya yang dilakukan oleh pemerintah adalah diterapkannya sistem penghitungan pajak self assessment system di Indonesia. Sistem ini merupakan sistem pemungutan pajak yang memberikan kepercayaan kepada wajib pajak untuk menghitung, membayar, dan melaporkanisendiri pajak yang terutang sesuai dengan ketentuan perpajakan yang berlaku. Namun beberapa studi seperti Noviati (1997); Damayanti (2004); dan Tarjo dan Kusumawati (2006) menemukan bahwa pelaksanaan self assessment system belum berjalan baik. Studi Novianti (1997) menemukan bahwa pelaksanaan self assessment belum bisa diterapkan oleh Wajib Pajak Orang Pribadi terutama pemilik koskosan, karena mereka sering kali tidak melaporkan atau mencantumkan pajak penghasilannya pada Surat Pemberitahuan (SPT).

Studi Damayanti (2004) menunjukkan bahwa self assessment system untuk Wajib Pajak Badan di Salatiga belum berjalan dengan baik. Studi Tarjo dan Kusumawati (2006) menemukan bahwa self assessement system di Bangkalan 
belum terlaksana dengan baik. Karena Wajib Pajak masih banyak yang tidak menghitung sendiri pajak terutangnya meskipun dalam fungsi membayar sudah baik karena Wajib Pajak telah menyetorkan pajak terutangnya sebelum jatuh tempo, tetapi ada Wajib Pajak yang membayar pajak terutang tidak sesuai dengan penghitungannya. Sedangkan dalam kasus pelaporan pajak, meskipun Wajib Pajak sudah melaksanakan pelaporan, namun hal itu dilakukan bukan karena kesadaran mereka sendiri tetapi karena adanya denda. Dalam hal ini peranan konsultan pajak sangat diperlukan, sebagai mitra dari pemerintah dalam hal ini direktorat jenderal pajak untuk membantu meningkatkan kesadaran akan pentingnya kepatuhan pajak bagi para wajib pajak.

Konsultan pajak merupakan salah satu profesi akuntansi yang sering mengalami dilema keputusan etis dalam menjalankan profesinya. Beberapa bulan terakhir profesi konsultan pajak menjadi salah satu profesi yang paling dibutuhkan oleh masyarakat. Hal ini terkait dengan kebijakan Tax Amnesty yang dikeluarkan oleh pemerintah Indonesia awal bulan Juli 2016 lalu. Para konsultan pajak khususnya konsultan pajak terdaftar di Bali-Nusa Tenggara mengalami peningkatan volume pekerjaan terkait dengan Tax Amnesty tersebut. Peningkatan pelayanan servis pajak tersebut tidak terlepas dari kekurangpahaman wajib pajak terhadap kebijakan Tax Amnesty dan kebijakan perpajakan lainnya, mengingat banyaknya peraturan baru terkait dengan peraturan perpajakan yang dikeluarkan pemerintah.

Devos (2012) menyatakan wajib pajak menggunakan konsultan pajak untuk mewakilinya dengan sejumlah alasan. Alasan-alasan yang dinyatakan 
I Made Dwi Harmana, Made Gede Wirakusuma' Dewa Gede Wirama, Pengaruh Idealisme...

Devos (2012) antara lain: keinginan untuk melaporkan SPT yang akurat terutama karena kurangnya pengetahuan pajak mereka berdasarkan kompleksitas hukum pajak saat ini, keinginan untuk meminimalkan pajak mereka yang diwajibkan untuk dibayar, ketakutan mereka akan membuat kesalahan dan dikenai sanksi, atau hanya karena kurangnya waktu untuk menyelesaikannya. Profesi di bidang akuntansi merupakan profesi yang penuh dengan masalah keputusan etis, karena profesi-profesi tersebut sering dihadapkan pada kondisi dilema etis, yang senantiasa mengancam kredibilitas dan integritas dari para profesional tersebut. Cash et al. (2007) menyatakan konsultan pajak harus terus memberikan pelayanan terbaik yang mereka bisa untuk kliennya, termasuk pengurangan pajak ketika hal itu dapat dilakukan dengan cara yang etis dan berdasarkan hukum dan dalam kepentingan terbaik dari klien. Gupta (2015) menemukan bahwa klien lebih memilih penjelasan yang terbatas dari implikasi peraturan perpajakan terkait dengan urusan pajak mereka dan kewajiban mereka berdasarkan hukum pajaknya. Studi Tan (1999) menemukan bahwa wajib pajak, yang adalah pemilik bisnis yang didominasi kecil, lebih setuju dengan rekomendasi konservatif yang diberikan oleh Konsultan Pajak. Menariknya, wajib pajak juga setuju, meskipun kurang kuat, dengan rekomendasi agresif dari Konsultan Pajak mereka. Sekjen Komwas Perpajakan dalam Achmad (2014) menyatakan:

"Profesi ideal konsultan pajak harus memiliki independensi, profesionalisme, dan integritas dalam menjalankan bisnis industrinya".

Konsultan pajak memiliki kode etik untuk menjaga independensi, profesionalisme, dan integritasnya dalam menjalankan profesinya. Disisi lain, studi Tan (1999) menunjukkan bahwa ada kecenderungan bagi klien yang tidak 
setuju dengan rekomendasi Konsultan Pajaknya dan memilih untuk mengakhiri penggunaan jasanya, meskipun tidak ada bukti yang jelas untuk menunjukkan bahwa ini hanya terjadi ketika keinginan mereka untuk rekomendasi konservatif tidak terpenuhi. Disinilah dibutuhkan pembuatan keputusan etis oleh seorang konsultan pajak. Blanthorne et al. (2014) menyatakan bahwa isu ini muncul sebagai akibat dari adanya masalah dual agency pada hubungan antara konsultan pajak dengan klien, di satu sisi konsultan pajak perlu membina hubungan baik dengan klien, namun di sisi lain konsultan pajak memiliki kewajiban untuk mematuhi peraturan pajak. Dilema etis yang dihadapi oleh konsultan pajak menghadapkan konsultan pajak untuk membuat suatu keputusan yang bertentangan dengan prinsip-prinsip profesionalitasnya,dengan imbalan ekonomis yang cukup material. Keputusan yang dibuat diharapkan tidak bertentangan dengan nilai-nilai etika. Pasal 28 dan 29 Peraturan Menteri Keuangan Nomor 111/PMK.03/2014 tentang Konsultan Pajak memberikan pengawasan yang sangat ketat bagi para konsultan pajak. Jika seorang konsultan pajak menangani suatu wajib pajak, dan pada akhirnya wajib pajak tersebut mengalami sengketa dan bahkan menjadi tersangka dalam tindak pidana perpajakan, maka ijin operasional konsultan pajak yang bersangkutan akan dibekukan dan bahkan dicabut. Salah satu kasus terkait dengan pembuatan keputusan yang tidak etis oleh konsultan pajak di Indonesia, adalah keterlibatan konsultan pajak Robertus Santonius dan Hendro Tirtawijaya dalam membantu wajib pajak yang ditanganinya untuk melakukan kecurangan. Kecurangan tersebut terungkap dalam kasus Gayus Tambunan dan Dhana Widyatmika (Harian Merdeka, 2012). Amarullah (2010) 
I Made Dwi Harmana, Made Gede Wirakusuma' Dewa Gede Wirama, Pengaruh Idealisme...

menyebutkan bahwa di Surabaya, terdapat kasus 13 konsultan pajak dijebloskan ke penjara karena memalsukan SSP dan uangnya tidak disetorkan tapi untuk keperluan pribadi serta berkonspirasi dengan lima PNS Pajak yang bertugas di lingkungan Kanwil Direktorat Jenderal Pajak Jatim I Jl Jagir Wonokromo, Surabaya. Selain pelanggaran kode etik yang menjurus pada pelanggaran pidana, terdapat pelanggaran etik lain juga yang tidak kalah penting yang seringkali diabaikan oleh konsultan pajak. Sebagai contoh, adanya saling "senggol” antara konsultan satu dengan lainnya karena perebutan klien, yang mana hal tersebut sebenarnya sudah diatur secara jelas dalam AD/ART IKPI tentang Kode Etik Konsultan Pajak.

Trevino (1986) menyatakan bahwa pembuatan keputusan etis seseorang akan sangat tergantung pada faktor-faktor individual dari orang yang membuat keputusan. Maka dari itu, dipandang perlu untuk mengkaji faktor-faktor yang dapat memperkuat pembuatan keputusan etis konsultan pajak, terutama dari faktor-faktor yang bersifat individu.

Salah satu hal yang yang dapat membantu seseorang dalam menghadapi dilema etika adalah orientasi etika. Orientasi etika merupakan alternatif pola perilaku seseorang untuk menyelesaikan dilema etika, yang salah satunya dibentuk oleh idealisme (Forsyth, 1980; Higgins dan Kelleher, 2005). Idealisme berkaitan dengan tindakan yang berpedoman pada nilai-nilai etika dan moral. Para profesional termasuk konsultan pajak yang memiliki idealisme tinggi seharusnya mampu menjaga independensi dan integritasnya dalam membuat suatu keputusan karena mereka tidak akan mudah untuk dipengaruhi oleh tawaran- 
tawaran imbalan ekonomis ataupun imbalan lainnya yang dapat menjatuhkan kredibilitas dan integritasnya sebagai praktisi di bidang perpajakan.

Pengalaman juga memberikan dampak pada setiap keputusan yang diambil oleh konsultan pajak sehingga diharapkan setiap keputusan yang diambil merupakan keputusan yang tepat. Hal tersebut mengindikasikan bahwa semakin lama masa kerja yang dimiliki konsultan pajak maka konsultan pajak akan semakin baik keputusan-keputusan yang dihasilkan. Penelitian Budi dkk. (2004) dan Oktavia (2006) tentang pengalaman kerja memberikan hasil bahwa tidak terdapat pengaruh pengalaman kerja terhadap pengambilan keputusan auditor, sementara dari penelitian Suraida (2005) menyatakan bahwa pengalaman audit dan kompetensi berpengaruh terhadap skeptisisme profesional dan ketepatan pemberian opini auditor akuntan publik. Begitu juga penelitian yang dilakukan Asih (2006), menemukan bahwa pengalaman auditor baik dari sisi lama bekerja, banyaknya tugas maupun banyaknya jenis perusahaan yang diaudit berpengaruh positif terhadap keahlian auditor dalam bidang auditing. Herliansyah dkk. (2006), dari penelitiannya menemukan bahwa pengalaman mengurangi dampak informasi tidak relevan terhadap judgment auditor. Konsultan pajak yang berpengalaman cenderung akan lebih berani dan lebih cepat dalam mengambil keputusan, mengingat pengalaman yang dimiliki dalam hal perpajakan. Namun sebaliknya, konsultan pajak dengan pengalaman yang tidak terlalu lama akan lebih berhatihati dalam pengambilan keputusan karena kurangnya pengalaman tersebut.

Alternatif lain yang dapat digunakan untuk menghadapi dilema etika adalah komitmen profesional. Larkin (1990) menyatakan bahwa komitmen 
I Made Dwi Harmana, Made Gede Wirakusuma' Dewa Gede Wirama, Pengaruh Idealisme...

profesional adalah loyalitas pada profesi yang dimiliki oleh individu. Komitmen profesional mengacu pada kekuatan identifikasi individu terhadap profesinya. Mowday et al. (1979) mengatakan bahwa individu dengan komitmen profesional yang tinggi memiliki kepercayaan dan penerimaan yang tinggi dalam tujuan profesi, berkeinginan untuk berusaha semaksimal mungkin atas nama profesi dan berkeinginan yang kuat untuk mempertahaankan eksistensinya dalam profesi. Secara khusus, komitmen profesi yang tinggi seharusnya mendorong para profesional ke perilaku yang sesuai dengan kepentingan publik dan menjauh dari perilaku yang membahayakan profesi (Aranaya dan Ferris, 1984). Lord dan DeZoort (2001) berpendapat bahwa auditor dengan komitmen profesi yang tinggi akan berperilaku selaras dengan kepentingan publik dan tidak akan merusak profesionalismenya. Sebaliknya, auditor dengan komitmen profesi yang rendah akan berpotensi untuk berperilaku disfungsional, misalnya perilaku yang mengutamakan kepentingan klien. Konsultan pajak yang memiliki komitmen profesional yang tinggi seharusnya tidak berperilaku disfungsional yang akan membahayakan kredibilitas profesinya.

Beberapa penelitian yang berhubungan dengan pembuatan keputusan etis telah dilakukan. Shaub et al. (1993) menemukan bahwa orientasi etika mempengaruhi sensitivitas etika, komitmen profesi dan organisasi. Penelitian Fallah (2006) menunjukkan bahwa budaya etis organisasi berpengaruh pada idealisme dan tidak berpengaruh pada relativisme, sedangkan relativisme berpengaruh signifikan pada sensitivitas etika dan idealisme tidak berpengaruh terhadap sensitivitas etika. Gusti dan Syahril (2007) menemukan bahwa skeptisme 
profesional dan situasi audit berpengaruhsignifikan terhadap ketepatan pemberian opini audit, sedangkan etika, pengalaman dan keahlian audit tidak berpengaruh signifikan terhadap ketepatan pemberian opini audit. Hasil penelitian Aziza dan Salim (2007) menunjukkan bahwa orientasi etika berpengaruh signifikan terhadap komitmen dan sensitivitas etika, sedangkan komitmen profesional dan organisasional tidak berpengaruh terhadap sensitivitas etika.

Januarti (2011) menemukan bahwa orientasi etis berpengaruh signifikan terhadap persepsi dan pertimbangan etis, sedangkan pengalaman, komitmen profesional, dan nilai etika organisasi tidak berpengaruh signifikan terhadap persepsi dan pertimbangan etis. Abdurrahman dan Yuliani(2011) meneliti tentang determinasi pembuatan keputusan etis auditor internal, hasil penelitiannya menunjukkan bahwa orientasi etika (yang diukur dengan indikator idealisme), komitmen profesional dan independensi berpengaruh signifikan terhadap pembuatan keputusan etis, sedangkan pengalaman auditor tidak berpengaruh terhadap pembuatan keputusan etis. Uyar dan Ozer (2011) menemukan bahwa orientasi etika berpengaruh signifikan pada pembuatan keputusan etis dan komitmen profesional, serta penelitian yang dilakukan oleh Ashari (2013) menemukan bahwa persepsi tentang korupsi berpengaruh terhadap perilaku antikorupsi, dukungan antikorupsi berpengaruh terhadap penilaian risiko,sensitivitas etika berpengaruh terhadap persepsi tentang korupsi, skeptisme profesional tidak berpengaruh terhadap sensitivitas etika dan skeptisme profesional berpengaruh terhadap penilaian resiko.

Tujuan penelitian ini adalah menguji pengaruh idealisme, pengalaman, 
I Made Dwi Harmana, Made Gede Wirakusuma' Dewa Gede Wirama, Pengaruh Idealisme...

dan komitmen profesional pada keputusan etis konsultan pajak. Perbedaan penelitian ini dengan penelitian sebelumnya adalah penggunaan objek, serta dimensi waktu dan tempat yang berbeda (confirmatory research). Perbedaan objek yang dimaksud adalah, penelitian ini dilakukan dengan menggunakan konsultan pajak terdaftar sebagai objeknya, sedangkan penelitian sebelumnya seluruhnya menggunakan auditor sebagai objek penelitiannya. Perbedaan dimensi waktu yang dimaksud adalah penelitian ini dilaksanakan pada tahun 2016, dan perbedaan dimensi tempat yang dimaksud adalah penelitian ini dilakukan pada seluruh konsultan pajak terdaftar di wilayah Bali-Nusa Tenggara. Alasan dipilihnya konsultan pajak sebagai responden dalam penelitian Ini karena beberapa penelitian sebelumnya lebih banyak menguji pembuatan keputusan etis auditor, baik auditor pemerintah seperti BPK, pemeriksa internal Bawasda maupun auditor independen, sedangkan sangat minim yang melakukan penelitian terhadap perilaku dari salah satu profesi penting dalam akuntansi, yaitu konsultan pajak. Faktor lain yang menjadi pertimbangan dipilihnya konsultan pajak terdaftar adalah budaya organisasi yang cenderung heterogen pada masing-masing konsultan pajak jika dibandingkan dengan auditor baik di pemerintahan maupun auditor independen. Auditor memiliki standar dalam melakukan audit, terutama standar pekerjaan lapangan, sedangkan standar tersebut tidak diatur secara jelas dalam profesi konsultan pajak.

Forsyth (1980) dan Shaubet al. (1993) mengidentifikasi idealisme sebagai salah satu prediktor penting penilaian moral. Sikap idealis diartikan sebagai sikap tidak memihak dan terhindar dari berbagai kepentingan. 
Shaub et al. (1993) menemukan bahwa orientasi etis mempengaruhi sensitivitas etika. Hasil penelitian Januarti (2011) menemukan bahwa orientasi etika berpengaruh signifikan terhadap persepsi dan pertimbangan etis. Abdurrahman dan Yuliani (2011) serta Uyar dan Ozer (2011) menemukan bahwa orientasi etika yang diukur dengan skala idealisme berpengaruh signifikan terhadap pembuatan keputusan etis. Hal ini bermakna bahwa semakin meningkat idealisme konsultan pajak, maka keputusan yang dibuat oleh konsultan pajak tersebut akan semakin etis. Berdasarkan penjelasan di atas, maka dapat dirumuskan hipotesis:

$H_{1}$ : Idealisme berpengaruh positif pada keputusan etis konsultan pajak terdaftar di Wilayah Bali-Nusa Tenggara.

Taftazani (2008) dalam penelitiannya menunjukkan bagaimana pengalaman dapat digunakan untuk meningkatkan kinerja pengambilan keputusan. Mariana (2009) menyatakan bahwa auditor yang berpengalaman akan memiliki keunggulan dalam hal mendeteksi kesalahan, memahami kesalahan dan mencari penyebab kesalahan. Pengalaman akan menghasilkan pengetahuan dan pengetahuan tersebut tersimpan di memori auditor, sehingga memori auditor memainkan peran penting pada kualitas pertimbangan. Sedangkan Frederick (1990) berpendapat bahwa akuntan pemeriksa yang berpengalaman memperlihatkan pengetahuan yang lengkap mengenai pengambilan keputusan pemeriksaan dalam laporan keuangan dan menghasilkan jumlah yang lebih banyak mengenai hipotesa penjelasan yang diteliti. 
I Made Dwi Harmana, Made Gede Wirakusuma' Dewa Gede Wirama, Pengaruh Idealisme...

Pengalaman adalah proses pembelajaran dan pertambahan potensi tingkah laku yang diperoleh dari pendidikan formal maupun non formal $\quad$ (Knoers dan Haditono, 1999). Standar Profesional Akuntan Publik (SPAP) menyatakan bahwa pelaksanaan audit harus dilakukan oleh orang yang memiliki keahlian dan pelatihan teknis yang cukup sebagai auditor. Penelitian Larkin (2000)menyatakan auditor yang memiliki pengalaman lebih konservatif saat menghadapi dilemma etika. Jones (1991) juga menyatakan bahwa perkembangan moral kognitif seseorang dipengaruhi oleh pengalaman. Hal ini menunjukkan bahwa pengalaman seorang konsultan pajak akan berkaitan dengan keputusan etis yang diambilnya. Berdasarkan penjelasan di atas maka dapat dirumuskan hipotesis:

$H_{2}$ : Pengalaman berpengaruh positif pada keputusan etis konsultan pajak terdaftar di Wilayah Bali-Nusa Tenggara.

Komitmen profesional merupakan loyalitas pada profesi yang dimiliki oleh individu (Larkin,1990). Penelitian Abdurrahman dan Yuliani (2011) menemukan bahwa komitmen profesional berpengaruh signifikan terhadap pembuatan keputusan etis. Jeffrey dan Weatherholt (1996), komitmen profesional yang kuat akan mengarahkan auditor untuk taat pada aturan. Hal ini bermakna bahwa semakin tinggi komitmen profesional konsultan pajak, maka keputusan yang dibuat oleh konsultan pajak tersebut akan semakin etis. Berdasarkan penjelasan di atas, maka dapat dirumuskan hipotesis:

$H_{3}$ : Komitmen profesional berpengaruh positif pada keputusan etis konsultan pajak terdaftar di Wilayah Bali Nusa-Tenggara. 


\section{METODE PENELITIAN}

Penelitian ini dilakukan tahun 2016 pada konsultan pajak terdaftar di Wilayah Bali-Nusa Tenggara sebagai representasi dari Konsultan Pajak di Indonesia, dikarenakan keterbatasan waktu dan biaya untuk melakukan penelitian. Seluruh konsultan pajak di Wilayah Bali-Nusa Tenggara berlokasi di Bali, Nusa Tenggara Barat, dan Nusa Tenggara Timur. Objek penelitian dalam penelitian ini adalah aspek keperilakuan terkait pengaruh idealisme, pengalaman, dan komitmen profesional pada pembuatan keputusan etis konsultan pajak pada konsultan pajak terdaftar di Wilayah Bali-Nusa Tenggara. Variabel terikat dalam penelitian ini adalah Keputusan Etis (Y). Variabel bebas dalam penelitian ini adalah perubahan Idealisme $\left(\mathrm{X}_{1}\right)$, Pengalaman $\left(\mathrm{X}_{2}\right)$, dan Komitmen Profesional $\left(\mathrm{X}_{3}\right)$.

Populasi penelitian ini adalah seluruh konsultan pajak terdaftar di Wilayah Bali Nusa Tenggara yang telah memiliki izin praktek sesuai Direktori IKPI (2016) sebanyak 114 orang konsultan pajak, serta masih berstatus aktif dan tidak dibatasi jabatannya, baik sebagai managing partner, manajer, konsultan senior, maupun konsultan junior. Pengambilan sampel yang digunakan dalam penelitian ini adalah dengan teknik purposivesampling. Adapun kriteria yang dijadikan dasar pemilihan anggota sampel pada penelitian ini adalah sebagai berkut: (1) konsultan pajak terdaftar dan memiliki ijin praktik di Wilayah Bali Nusa Tenggara; (2) masih berstatus aktif yang tidak dibatasi jabatannya, baik sebagai managing partner, manajer, konsultan senior, maupun konsultan junior; (3) sekurang-kurangnya menangani lima wajib pajak badan. Metode pengumpulan 
I Made Dwi Harmana, Made Gede Wirakusuma' Dewa Gede Wirama, Pengaruh Idealisme...

data yang digunakan dalam penelitian ini adalah metode survei dengan teknik kuesioner. Kuesioner yang disebarkan berupa daftar pertanyaan dan pernyataan tertulis kepada responden mengenai pengaruh idealisme, pengalaman, dan komitmen profesional pada pembuatan keputusan etis konsultan pajak. Pengukuran variabel menggunakan skala Likert empat poin untuk menghindari multi interpretable dan central tendency effect. Skala Likert merupakan skala yang digunakan untuk mengukur sikap, pendapat, dan persepsi seseorang atau sekelompok orang tentang fenomena sosial, dan jika skala ini digunakan dalam pengukuran akan menghasilkan data interval atau rasio (Sugiyono,2009). Penelitian-penelitian sebelumnya ada yang menggunakan rentang nilai skala Likert 1 sampai dengan 5 dan 1 sampai dengan 7, sedangkan dalam penelitian ini digunakan rentang nilai 1 sampai 4. Modifikasi skala Likert ini mengacu pada pendapat Hadi (1991) untuk beberapa alasan berikut: Pertama, pemberian kategori tengah memberikan arti ganda atau multi interpretable. Kedua, tersedianya kategori jawaban tengah menimbulkan kecenderungan jawaban ketengah (central tendency effect) bagi konsultan pajak yang memiliki keraguan dalam menanggapi pernyataan. Ketiga, jika disediakan kategori jawaban tengah akan menghilangkan banyak informasi dari para konsultan pajak. Teknik analisis data yang digunakan dalam penelitian ini adalah teknik analisis regresi linier berganda. 


\section{HASIL DAN PEMBAHASAN}

\section{Sampel Penelitian}

Tabel 1.

Data Pengambilan Sampel

\begin{tabular}{lc}
\hline \multicolumn{1}{c}{ Keterangan } & Jumlah \\
\hline Kuesioner yang disebarkan & 114 \\
Kuisioner yang tidak kembali & 2 \\
Kuisioner yang kembali & 112 \\
Kuisioner yang diisi oleh konsultan pajak yang & \\
menangani kurang dari 5 (lima) WP Badan & 22 \\
Sampel Penelitian & 90 \\
Kuisioner yang tidak lengkap & 0 \\
Kuesioner yang digunakan & 90
\end{tabular}

Tingkat pengembalian (Response rate) :

$$
112 / 114 \times 100 \%=98,25 \%
$$

Tingkat kuisioner yang dapat digunakan (Usable response rate) :

$$
90 / 112 \times 100 \%=80,36 \%
$$

Sumber: Hasil Penelitian 2016

Tabel 1. menunjukkan bahwa jumlah kuesioner yang disebarkan kepada responden sebanyak 114 kuesioner, yang dikembalikan sebanyak 112 kuesioner (response rate 98,25\%), dan setelah diperiksa terdapat 22 kuisioner diisi oleh konsultan pajak yang menangani kurang dari 5 wajib pajak badan, sehingga secara keseluruhan yang layak digunakan untuk analisis lebih lanjut adalah sebanyak 90 kuesioner (usable response rate 80,36\%). 


\section{Uji Instrumen}

Tabel 2

Hasil Uji Validitas

\begin{tabular}{|c|c|c|c|c|}
\hline Variabel & $\begin{array}{c}\text { Kode } \\
\text { Instrumen }\end{array}$ & $\begin{array}{l}\text { Nilai Pearson } \\
\text { Correlation }\end{array}$ & Signifikansi & Keterangan \\
\hline \multirow{6}{*}{ Idealisme (X1) } & $\mathrm{X} 1.1$ & 0,731 & 0,000 & Valid \\
\hline & $\mathrm{X} 1.2$ & 0,696 & 0,000 & Valid \\
\hline & $\mathrm{X} 1.3$ & 0,856 & 0,000 & Valid \\
\hline & X1.4 & 0,543 & 0,000 & Valid \\
\hline & $\mathrm{X} 1.5$ & 0,491 & 0,000 & Valid \\
\hline & X1.6 & 0,604 & 0,000 & Valid \\
\hline \multirow{4}{*}{ Pengalaman (X2) } & $\mathrm{X} 2.1$ & 0,755 & 0,000 & Valid \\
\hline & $\mathrm{X} 2.2$ & 0,710 & 0,000 & Valid \\
\hline & $\mathrm{X} 2.3$ & 0,711 & 0,000 & Valid \\
\hline & $\mathrm{X} 2.4$ & 0,799 & 0,000 & Valid \\
\hline \multirow{7}{*}{$\begin{array}{l}\text { Komitmen Profesional } \\
\text { (X3) }\end{array}$} & X3.1 & 0,838 & 0,000 & Valid \\
\hline & X3.2 & 0,773 & 0,000 & Valid \\
\hline & $\mathrm{X} 3.3$ & 0,434 & 0,000 & Valid \\
\hline & X3.4 & 0,854 & 0,000 & Valid \\
\hline & $\mathrm{X} 3.5$ & 0,780 & 0,000 & Valid \\
\hline & X3.6 & 0,758 & 0,000 & Valid \\
\hline & X3.7 & 0,886 & 0,000 & Valid \\
\hline \multirow{5}{*}{$\begin{array}{c}\text { Pembuatan Keputusan } \\
\text { Etis (Y) }\end{array}$} & X3.8 & 0,890 & 0,000 & Valid \\
\hline & Y1 & 0,592 & 0,000 & Valid \\
\hline & $\mathrm{Y} 2$ & 0,804 & 0,000 & Valid \\
\hline & Y3 & 0,876 & 0,000 & Valid \\
\hline & Y4 & 0.915 & 0,000 & Valid \\
\hline
\end{tabular}

Sumber : Hasil Penelitian 2016

Hasil uji validitas disajikan pada Tabel 2 di atas, menunjukkan bahwa tidak ada masalah dengan validitas atas instrumen yang digunakan dalam penelitian ini karena nilai Pearson Correlation pad masing-masing indikator di atas 0,3 (Gozhali, 2013). 


\section{Tabel 3}

Hasil Uji Reliabilitas

\begin{tabular}{clcc}
\hline No & \multicolumn{1}{c}{ Variabel } & Cronbach Alpha & Keterangan \\
\hline 1 & Idealisme (X1) & 0,714 & Reliabel \\
2 & Pengalaman (X2) & 0,712 & Reliabel \\
3 & Komitmen Profesional (X3) & 0,889 & Reliabel \\
4 & Pembuatan Keputusan Etis (Y) & 0,796 & Reliabel \\
\hline
\end{tabular}

Sumber :Hasil Penelitian 2016

Hasil uji reliabilitas menunjukkan nilai Cronbach Alpha di atas 0,70 sehingga dapat disimpulkan bahwa semua variabel reliabel dalam penelitian ini.

\section{Uji Asumsi Klasik}

Tabel 4

Rangkuman Hasil Uji Asumsi Klasik

\begin{tabular}{ccccc}
\hline \multirow{2}{*}{ Variabel } & Normalitas & \multicolumn{2}{c}{ Multikolinearitas } & Heterokedastisitas \\
& & Tolerance & VIF & \\
\hline Idealisme & 0,667 & 1,476 & 0,520 \\
Pengalaman & 0,064 & 0,600 & 1,665 & 0,993 \\
$\begin{array}{c}\text { Komitmen } \\
\text { Profesional }\end{array}$ & & 0,638 & 1,566 & 0,931 \\
\hline
\end{tabular}

Sumber: Hasil Penelitian 2016

Hasil uji normalitas menunjukkan nilai Kolmogorov-Smirnov adalah

0,448 dan koefisien Asymp. sig (2-tailed) =0,064, lebih besar dari $\alpha=0,05$ artinya, semua variabel dalam penelitian ini berdistribusi normal.

Hasil uji multikolinearitas menunjukkan bahwa nilai tolerance lebih besar dari $10 \%$ dan nilai VIF lebih kecil atau kurang dari 10. Hal ini mengindikasikan bahwa dalam penelitian ini tidak terjadi multikolinearitas. 
I Made Dwi Harmana, Made Gede Wirakusuma' Dewa Gede Wirama, Pengaruh Idealisme...

Hasil uji heterokedastisitas menunjukkan bahwa variable idealisme, komitmen profesional dan skeptisme profesional tidak berpengaruh signifikan terhadap pembuatan keputusan etis, karena signifikansi setiap variabel bebas lebih dari taraf nyata $(\alpha)$ yaitu 5\%. Jadi dapat disimpulkan bahwa tidak terjadi heteroskedastisitas.

Tabel 5

Statistik Deskriptif

\begin{tabular}{lccccc}
\hline \multicolumn{1}{c}{ Variabel } & N & Min. & Max. & Mean & $\begin{array}{c}\text { Standar } \\
\text { deviation }\end{array}$ \\
& 90 & 16 & 24 & 20,5778 & 1,87220 \\
Idealisme & 90 & 8 & 16 & 12,3222 & 2,10312 \\
Pengalaman & 90 & 24 & 32 & 27,7444 & 3,04853 \\
Pemitmen Profesional & 90 & 11 & 16 & 13,0667 & 1,74691 \\
\hline
\end{tabular}

Sumber: Hasil Penelitian 2016

Berdasarkan Tabel 5 di atas, Variabel idealisme memiliki nilai minimum sebesar 16, nilai maksimum 24, Rata-rata respon responden yang menjawab pernyataan didalam kuisioner dengan untuk variabel idealisme adalah sebesar 20,5778 masuk dalam klasifikasi cukup tinggi dimana sebagian besar responden memiliki tingkat jawaban setuju didalam indikator-idikator Idealisme yaitu: evaluasi tindakan, toleransi, tindakan fisik \& psikologis, serta penilaian moral.

Variabel pengalaman memiliki nilai minimum sebesar 8, nilai maksimum 16. Rata-rata respon responden untuk variabel Pengalaman sebesar 12,3222 masuk dalam klasifikasi cukup tinggi dimana sebagian besar responden memiliki tingkat jawaban setuju didalam indikator-idikator Pengalaman yaitu: jabatan, 
lamanya bekerja sebagai konsultan, jumlah pelatihan perpajakan/ PPL yang pernah diikuti, dan jumlah wajib pajak badan yang ditangani.

Variabel komitmen profesional memiliki nilai minimum sebesar 24, nilai maksimum 32. Rata-rata respon responden untuk variabel Komitmen Profesional sebesar 27,7444 masuk dalam klasifikasi komitmen profesional cukup tinggi dimana sebagian besar responden memiliki tingkat jawaban setuju didalam indikator-indikator Komitmen Profesional yaitu: kesadaran dan sikap sukarela, kebanggan pada profesi, motivasi, pengorbanan, pengembangan diri, dan kepedulian pada profesi.

Variabel pembuatan keputusan etis memiliki nilai minimum sebesar 11,

nilai maksimum 16. Rata-rata respon responden untuk variabel Pembuatan Keputusan Etis sebesar 13,0667 masuk dalam klasifikasi Pembuatan Keputusan Etis cukup tinggi dimana responden cenderung menjawab setuju didalam kasuskasus positif yang berkaitan dengan pembuatan keputusan etis dan menjawab tidak setuju pada kasus-kasus negatif yang berkaitan dengan pembuatan keputusan etis konsultan pajak.

\section{Pengujian Hipotesis}

Tabel 6

Rangkuman Hasil Analisis Regresi Linier Berganda

\begin{tabular}{lcccc}
\hline Variabel & $\begin{array}{c}\text { Koefisien } \\
\text { Regresi }\end{array}$ & Statistik t & Signifikansi & Keterangan \\
\hline Konstanta & 1,178 & & & \\
Idealisme` & 0,218 & 2,375 & 0,020 & Signifikan \\
Pengalaman & 0,237 & 2,738 & 0,008 & Signifikan \\
$\begin{array}{l}\text { Komitmen } \\
\text { Profesional }\end{array}$ & 0,162 & 2,792 & 0,006 & Signifikan
\end{tabular}


F-Test $\quad=0,000$

Adjusted $R^{2}=0,419$

Sumber: Hasil Penelitian 2016

Hasil uji statistik menunjukkan bahwa idealisme, pengalaman, dan komitmen profesional berpengaruh positif dan signifikan pada keputusan etis konsultan pajak di wilayah Bali-Nusa Tenggara. Nilai adjusted $\mathrm{R}^{2}$ sebesar 0,419 memiliki arti bahwa sebesar 41,9\% variasi perubahan keputusan etis konsultan pajak di wilayah Bali-Nusa Tenggara ditentukan oleh variabel idealisme, pengalaman, dan komitmen profesional. Sedangkan sisanya sebesar 58,1\% ditentukan oleh variabel-variabel lain yang tidak dijelaskan dalam penelitian ini.

Pengaruh masing-masing variabel bebas pada variabel terikat dipaparkan pada pembahasan berikut ini. Hipotesis pertama $\left(\mathrm{H}_{1}\right)$ menyatakan bahwa idealisme berpengaruh positif pada keputusan etis konsultan pajak di wilayah Bali-Nusa Tenggara. Hasil uji statistik pada Tabel 6 menunjukkan nilai koefisien regresi sebesar 0,218 dengan signifikansi 0,020. Hal ini memiliki arti bahwa idealisme berpengaruh positif pada keputusan etis, atau semakin tinggi idealisme dari konsultan pajak maka keputusan yang dibuatnya akan semakin etis, maka hipotesis pertama $\left(\mathrm{H}_{1}\right)$ dalam penelitian ini diterima. Dalam instrumen penelitian untuk variabel idealisme, secara implisit disajikan pernyataan-pernyataan yang mempertimbangkan kebaikan bagi masyarakat serta ketaatan hukum, dimana konsultan pajak dalam membuat keputusan setidaknya tidak boleh melanggar hakhak dari pihak lain baik yang berinteraksi secara langsung maupun yang tidak berinteraksi secara langsung dengan konsultan pajak. Sesuai dengan Cognitive Moral Development Theory pada Post-Conventional level, bahwa orang mulai 
mempertimbangkan hal-hal yang baik bagi masyarakat akan tetapi tetap taat pada aturan hukum yang berlaku dalam membuat suatu keputusan yang etis. Hasil penelitian ini konsisten dengan penelitian Aziza dan Salim (2007) yang menyatakan bahwa orientasi etika yang diukur dengan indikator-indikator idealisme berpengaruh positif terhadap kepekaan auditor terhadap masalahmasalah etis. Hasil penelitian ini juga diperkuat oleh penelitian Januarti (2011) yang menyatakan bahwa orientasi etika yang diproksikan dengan idealisme berpengaruh positif dan signifikan terhadap persepsi dan pertimbangan etis auditor. Hasil penelitian ini juga searah dengan penelitian Uyar dan Ozer (2011) yang menyatakan akuntan yang memiliki idealisme yang tinggi cenderung untuk tidak membuat keputusan yang bertentangan dengan nilai-nilai moral dibandingkan dengan akuntan yang memiliki sikap relativis. Sedangkan, hasil penelitian ini tidak sejalan dengan penelitian Fallah (2006) yang menyatakan bahwa idealisme tidak berpengaruh terhadap sensitivitas etika, yang kemungkinan disebabkan karena persepsi responden yang menganggap bahwa hal yang tidak etis hanya jika hal tersebut merugikan orang lain, tanpa memperhatikan sikap yang harus dimiliki. Secara umum, hasil penelitian ini menunjukkan bahwa konsultan pajak yang memiliki idealisme tinggi, akan cenderung membuat keputusan yang semakin etis. Sehingga, idealisme sebaiknya dipertahankan oleh konsultan pajak dalam membuat keputusan-keputusan yang tepat ketika menghadapi dilema etika.

Hipotesis kedua $\left(\mathrm{H}_{2}\right)$ menyatakan bahwa pengalaman berpengaruh positif pada keputusan etis konsultan pajak di wilayah Bali-Nusa Tenggara. Hasil uji 
I Made Dwi Harmana, Made Gede Wirakusuma' Dewa Gede Wirama, Pengaruh Idealisme...

statistik pada Tabel 6 menunjukkan nilai koefisien regresi sebesar 0,237 dengan signifikansi 0,013. Hal ini memiliki arti bahwa pengalaman berpengaruh positif pada keputusan etis, atau semakin berpengalaman seorang konsultan pajak maka keputusan yang dibuatnya akan semakin etis, maka hipotesis kedua $\left(\mathrm{H}_{2}\right)$ dalam penelitian ini diterima. Hasil penelitian ini searah dengan penelitian Nadirsyah (2007) yang menyatakan bahwa pengalaman auditor berpengaruh positif terhadap keputusan etis auditor. Auditor yang memiliki pengalaman dianggap lebih konservatif saat mengahadapi dilema etika (Larkin, 2000). Sikap konservatif tersebut membantu auditor untuk meningkatkan sensitivitas etikanya. Gusnardi (2003) mengukur pengalaman audit melalui jabatan auditor, lama bekerja, peningkatan keahlian, serta pelatihan audit yang pernah diikuti. Penggunaan pengalaman didasarkan pada asumsi bahwa tugas yang dilakukan secara berulang-ulang memberikan peluang untuk belajar melakukannya dengan yang terbaik . Sedangkan, hasil penelitian ini tidak sejalan dengan penelitian Singgih (2010) yang menyatakan bahwa pengalaman auditor tidak berpengaruh terhadap kualitas audit, yang disebabkan sebagian besar responden dalam penelitian mereka adalah auditor yang menjabat sebagai junior dan masa kerjanya tidak lebih dari 3 tahun sehingga respon para responden untuk menjawab pertanyaan berkaitan dengan variabel pengalaman cenderung menghasilkan jawaban tidak bernilai positif. Secara umum, hasil penelitian ini menunjukkan bahwa konsultan pajak yang semakin berpengalaman, akan cenderung membuat keputusan yang semakin etis. Sehingga, pengembangan pengalaman sebaiknya dipertahankan oleh konsultan 
pajak dalam membuat keputusan-keputusan yang tepat ketika menghadapi dilema etika.

Hipotesis ketiga $\left(\mathrm{H}_{3}\right)$ menyatakan bahwa komitmen profesional berpengaruh positif pada pembuatan keputusan etis konsultan pajak di wilayah Bali-Nusa Tenggara. Hasil uji statistik pada Tabel 6 menunjukkan nilai koefisien regresi sebesar 0,162 dengan signifikansi 0,006. Hal ini memiliki arti bahwa komitmen profesional berpengaruh positif pada pembuatan keputusan etis, atau semakin tinggi komitmen dari konsultan pajak terhadap profesinya, maka keputusan yang dibuatnya akan semakin etis, maka hipotesis ketiga $\left(\mathrm{H}_{3}\right)$ dalam penelitian ini diterima. Hasil penelitian ini konsisten dengan penelitian Abdurrahman dan Yuliani (2011) yang menyatakan bahwa komitmen auditor terhadap profesinya berpengaruh positif terhadap pembuatan keputusan etis. Sedangkan, hasil penelitian ini tidak sejalan dengan penelitian Aziza dan Salim (2007) yang menyatakan bahwa komitmen profesional tidak berpengaruh terhadap kepekaan auditor terhadap masalah-masalah etis. Hasil penelitian ini juga bertentangan dengan penelitian Januarti (2011) yang menyatakan komitmen profesional tidak berpengaruh terhadap persepsi dan pertimbangan etis. Hal ini kemungkinan disebabkan karena kurangnya peranan organisasi profesi dalam memberikan responden kesempatan untuk mengembangkan diri melalui pelatihanpelatihan maupun forum diskusi, sehingga responden tidak menganggap komitmen profesional sebagai sesuatu yang penting. Secara umum, hasil penelitian ini menunjukkan bahwa konsultan pajak yang memiliki komitmen profesional yang tinggi, akan cenderung membuat keputusan yang semakin etis. 
I Made Dwi Harmana, Made Gede Wirakusuma' Dewa Gede Wirama, Pengaruh Idealisme...

Sehingga, komitmen profesional sebaiknya dipertahankan oleh konsultan pajak untuk membuat keputusan yang tepat ketika berada dalam kondisi dilema etika.

\section{SIMPULAN DAN SARAN}

Berdasarkan latar belakang, rumusan masalah, tujuan penelitian, kajian teori, kajian empiris, hipotesis, serta hasil pengujian statistik, maka dapat disimpulkan sebagai berikut; Idealisme berpengaruh positif pada keputusan etis konsultan pajak terdaftar di wilayah Bali-Nusa Tenggara. Hal ini memiliki arti bahwa semakin idealis konsultan pajak, maka keputusan yang dibuat akan semakin etis. Pengalaman berpengaruh positif pada keputusan etis konsultan pajak terdaftar di wilayah Bali-Nusa Tenggara. Hal ini memiliki arti bahwa semakin berpengalaman seorang konsultan pajak, maka keputusan yang dibuat akan semakin etis. Komitmen Profesional berpengaruh positif pada keputusan etis konsultan pajak di wilayah Bali-Nusa Tenggara. Hal ini memiliki arti bahwa semakin tinggi komitmen konsultan pajak terhadap profesinya, maka keputusan yang akan dibuat akan semakin etis.

Jadi, idealisme, pengalaman, dan komitmen profesional sebaiknya senantiasa dipertahankan oleh konsultan pajak, karena ketiga variabel tersebut dapat membantu konsultan pajak untuk membuat keputusan-keputusan yang etis pada saat menghadapi dilema etika.

Saran yang dapat diberikan berdasarkan atas simpulan dan pembahasan hasil di atas adalah; berdasarkan hasil jawaban responden pada variabel idealisme, perlu ditingkatkan pemahaman seorang konsultan pajak dalam menerapkan 
strategi perencanaan pajak yang sesuai dengan peraturan perpajakan yang berlaku. Sehingga seorang konsultan pajak diharapkan mampu menjaga idealismenya dalam menjalankan profesinya sebagai perpanjangan tangan dari pemerintah untuk meningkatkan penerimaan pajak Negara dan meningkatkan kepatuhan wajib pajak. Berdasarkan jawaban responden pada variabel pengalaman, konsultan pajak terdaftar di wilayah Bali-Nusa Tenggara memiliki lama pengalaman yang relatif singkat, namun hal tersebut bisa ditingkatkan lagi karena selain lama bekerja sebagai seorang konsultan pajak, jumlah wajib pajak yang ditangani dan tingkat kompleksitas wajib pajak yang ditangani juga menjadi pertimbangan penting dalam meningkatkan pengalaman seorang konsultan pajak. Respon responden pada variabel komitmen professional menunjukkan perlunya suatu upaya dari konsultan pajak sendiri untuk menumbuhkan rasa bangga pada dirinya sebagai seorang konsultan pajak. Sehingga seorang konsultan pajak mampu menjaga profesionalitasnya dengan membuat suatu keputusan yang baik dalam setiap masalah perpajakan yang dialami oleh wajib pajak yang ditangani. Berdasarkan jawaban responden pada variabel pembuatan keputusan etis, masih ada konsultan pajak yang beranggapan bahwa perpindahan seorang konsultan dari kantor konsultan pajak satu ke kantor konsultan pajak lainnya dengan membawa serta klien yang mereka tangani merupakan hal yang wajar. Hal ini perlu ditegaskan lebih lanjut lagi karena permasalahan saling merebut klien antar konsultan pajak cukup sering terjadi, padahal ketentuan tentang hal itu sudah dijelaskan dalam AD/ART Kode Etik Konsultan Pajak. Nilai Adjusted $\mathrm{R}^{2}$ sebesar 0,419, ini menunjukkan bahwa sebesar $41,9 \%$ pembuatan keputusan etis 
I Made Dwi Harmana, Made Gede Wirakusuma' Dewa Gede Wirama, Pengaruh Idealisme...

konsultan pajak terdaftar di wilayah Bali-Nusa Tenggara dipengaruhi oleh variabel idealisme, pengalaman, dan komitmen profesional, sedangkan 58,1\% dipengaruhi oleh variabel-variabel lain yang tidak disajikan dalam model penelitian ini. Hal ini menjadi peluang bagi penelitian selanjutnya untuk mengembangkan penelitian terkait dengan pembuatan keputusan etis konsultan pajak.

\section{REFERENSI}

Abdurrahman, dan Yuliani, Nur L. 2011. Determinasi Pengambilan Keputusan Etis Auditor Internal (Studi Empiris Pada BUMN dan BUMD di Magelang dan Tumanggung). Widya Warta, 2 pp. 133-150.

Achmad, T. 2014. Menjadikan Konsultan Pajak sebagai Agents of Tax Compliance. Website: http://www.pajak.go.id/ content/article/menjadikankonsultan-pajak-sebagai-agents-taxcompliance.

Amarullah, A. 2010. 13 Konsultan Pajak di Surabaya Ditahan. Website: http:// nasional.news.viva.co.id/news/read/148362-13_konsultan_pajak_ di_surabaya_ditahan.

Aranya, N., A. Barack and Amernic, J. 1981. A test of Holland's theory in a population of accountants. Journal of Vocational Behavior. 19, pp. 1524.

, and K. R. Ferris. 1984. A Reexamination of Accountants' OrganizationalProfesional Conflict. The Accounting Review. 59, pp.1-15.

Arestanti, M.A. 2016. Faktor-Faktor Internal Individual dalam Pembuatan Keputusan Etis: Studi pada Konsultan Pajak di Kota Surabaya. Jurnal Akuntansi dan Investasi, 17(2), pp: 104-117

Ashari, 2013. Corruption Awareness, Ethical Sensitivity, Professional Skepticism And Risk Of Corruption Assessment: Exploring The Multiple Relationship In Indonesian Case. Available from: www.ssrn.com.

Aziza, N. dan Salim A. 2007. Pengaruh Orientasi Etika Pada Komitmen dan Sensitivitas Etika Auditor (Studi Empiris pada Auditor di Bengkulu dan Sumatera Selatan). Simposium Nasional Akuntansi XI. Pontianak 23 - 24 
Juli 2008 .

Bertens, K. 2000. Pengantar Etika Bisnis. Yogyakarta:Kanisius.

Blanthorne, C., H. A. Burton dan Fisher, D. 2014. The Aggressiveness of Tax Professional Reporting: Examining the Influence of Moral Reasoning. Advances in Accounting Behavioral Research, 16, 149 - 181.

Brooks, Leonard J. 2007. Business and Professional Ethics. Thompson South Western.

Butt, J. L. 1988. Frequency Judgment In An Auditing Related Task. Journal of Accounting Research. 26.

Cash, L. S., T. L. Dickens dan M. E. Mowrey 2007. The Ethics Environment in Which Tax Professionals Practice. Taxes-The Tax Magazine, 43-55.

Devos, K. 2012. The Impact of Tax Professionals Upon the Compliance Behavior of Australian Individual Taxpayers, Revenue Law Journal, 22 (1), 1-26.

Duska, Ronald, F., and Brenda, S. 2003. Accounting Ethics. Blackwell Publishing Ltd.

Fallah, Syaikhul. 2006. "Pengaruh Budaya Etis Organisasi Dan Orientasi Etika Terhadap Sensitivitas Etika (Studi Empiris Tentang Pemeriksa Internal di Bawasda Pemda Papua)" (tesis). Semarang: Universitas Diponegoro.

Finn, Don W., Lawrence B., Chonko, and Shelby, D. Hunt. 1988. Ethical Problems in Public Accounting: The View From the Top. Journal of Business Ethics. 7, pp. 605-615.

Forsyth, D. R. 1980. A Taxonomy of Ethical Ideology. Journal of Personality and Social Psychology. 39, pp. 175-184.

Ghozali, Imam. 2013. Aplikasi Analisis Multivariate dengan Program SPSS. Edisi ke 7. Semarang: Universitas Diponegoro.

Gupta, R. 2015. Relational Impact of Tax Practitioners' Behavioural Interaction dan Service Satisfaction: Evidence from New Zealand. eJournal of Tax Research, 13 (1), 76-107.

Gusti, M. dan Syahril, Ali. 2007. Hubungan Skeptisisme Profesional Auditor Dan Situasi Audit, Etika, Pengalaman Serta Keahlian Audit Dengan Ketepatan Pemberian Opini Auditor Oleh Akuntan Publik. Simposium Nasional Akuntansi XI. Pontianak 23 - 24 Juli 2008. 
I Made Dwi Harmana, Made Gede Wirakusuma' Dewa Gede Wirama, Pengaruh Idealisme...

Hadi, Sutrisno. 1991. Analisa Butir untuk Instrumen Angket, Test dan Skala Rating. Yogyakarta: Andi Offeset

Halim, Abdul. 2008. Dasar-Dasar Audit Laporan Keuangan.Yogyakarta: YKPN

Higgins and Kelleher. 2005. Comparative Perspectives on the Ethical Orientations of Human Resources, Marketing and Finance Functional Managers. Journal of Business Ethics. 56, pp. 275-288.

Hunt, S. D. and S. J. Vitell. 1986. A General Theory of Marketing Ethics. Journal of Macromarketing. Spring pp. 5-16.

Januarti, Indira. 2011. Analisis pengaruh pengalaman auditor, komitmen profesional, orientasi etis, dan nilai etika terhadap persepsi dan pertimbangan etis (auditor badan pemeriksa keuangan Indonesia). Simposium Nasional Akuntansi XIV. Aceh 20 - 23 Juli 2011.

Jones, T. M. 1991. Ethical Decision Making by Individuals in Organizations : An Issue Contingent Model. Academy of Management Review. 16, pp. 366395.

Jeffrey, C. and Weatherholt, N. 1996. Ethical Development, Professional Commitment, and Rule Observance Attitudes: A Study Case of CPAs and Corporate Accountans. Behavioral Research in Accounting. 8, pp. 8-36.

Jogiyanto. 2007. Metode Penelitian Bisnis: Salah Kaprah dan PengalamanPengalaman. Yogyakarta: BPFE.

Kee, H.W. and Knox, R.E. 1976. Conceptual and Metoda Logical Considerations in The Study of Trust and Suspicion. Journal of Conflict Resolution. 14, pp. 357-366.

Kerlinger, Fred N. 2003. Asas-Asas Penelitian Behavioral. Yogyakarta: Gadjah Mada University Press.

Kohlberg, L. 1969. Stage and Sequance: The Cognitive Developmental Approach to Socialization in D.A Goslin. Chicago: Rand McNally. Handbook of Socialization Theory and Research. pp. 347-480.

Kwon, I. W. G., and Banks, D. W. 2004. Factors Related To The Organizational And Professional Commitment Of Internal Auditors. Managerial Auditing Journal. 19, pp. 606-622.

Larkin, J. M. 1990. Does Gender Affect Auditor KAPs' Performance?. The Woman CPA. Spring pp. 20-24. 
Lord, A. T., and DeZoort, F.T. 2001. The Impact Of Commitment And Moral Reasoning On Auditors'responses To Social Influence Pressure.Accounting. Organizations And Society. 26, pp. 215-235.

Louwers, T. J., Ponemon, L. A., and Radtke, R. R. 1997. Examining accountants ethical behaviour: A review and implication for future research. American Accounting Association.

Mowday, R. T., Steers, R. M., and Porter, L. W. 1979. The Measurement of Organizational Commitment. Journal of Vacational Behavioral. 14, pp. 224-247.

Peraturan Menteri Keuangan Republik Indonesia Nomor 111/PMK.03/2014 Tentang Konsultan Pajak.

Shaub, M. K., Don, W. Finn and Paul, Munter. 1993. The Effects of Auditor's Ethical Orientation on Commitment and Ethical Sensitivity. Behavioral Research in Accounting. 5, pp. 145-169.

, and Lawrence, Jenice E. 1996. Ethics Experience and Professional Scepticism: A Situational Analysis. Behavioral Research In Accounting. 8, pp. 124-157.

Suardika, 2015. Pengaruh Idealisme, Komitmen Profesional, dan Skeptisme Profesional pada Pembuatan Keputusan Etis Konsultan Pajak di Provinsi Bali (tesis) Denpasar: Universitas Udayana.

Sugiyono. 2010. Metode Penelitian Bisnis Kuantitatif, Kualitatif dan R\&D. Bandung: PT. Alfabeta Cipta.

Tan, L. M. 1999. Taxpayers' Preference for Type of Advice from Tax Practitioner: A Preliminary Examination. Journal of Economic Psychology, 20 (4), 431-447.

Trevino, Linda Klebe. 1986. Ethical Decision Making in Organization: A Person Situation Interactionist Model. Academy of Management Review Review. pp. 601-617.

Uyar,M., and Ozer, G. 2011. The Ethical Orientation And Professional Commitment: An Empirical Examination On Turkish Accountants. Available from: www.ssrn.com.

Setuningsih, N. 2016. Penerimaan Pajak 2016 Capai Rp 1.032 T. http://www.beritasatu.com/ekonomi/406132-penerimaan-pajak-2016capai-rp-1032-t.html. diunduh 17 Januari 2017. 
I Made Dwi Harmana, Made Gede Wirakusuma' Dewa Gede Wirama, Pengaruh Idealisme...

Kementrian Keuangan. www.kemenkeu.go.id/Berita/menkeu-tax-ratio-indonesiadi-bawah-standar. diunduh 19 Januari 2017. 